\title{
En ung mann med akutte generaliserte ødemer
}

\author{
$\emptyset$ demer og hypoalbuminemi er en vanlig problemstilling i en indremedi- \\ sinsk avdeling. Vi presenterer sykehistorien til en ung, tidligere frisk \\ mann som ble innlagt pga. akutt oppståtte ødemer og hypoproteinemi.
}

Se kommentar side 1629 og kunnskapsprøve på www.tidsskriftet.no/quiz

\section{Trond Engjom \\ trond.engjom@helse-bergen.no \\ Gastroseksjonen \\ Medisinsk avdeling \\ Kristin Kampevold Larsen \\ Avdeling for patologi \\ Haukeland universitetssykehus \\ 5021 Bergen}

\section{Oddbjørn Hove}

Forskningsseksjonen

Klinikk for psykisk helsevern

Helse Fonna HF

\section{Odd Helge Gilja}

Nasjonalt senter for gastroenterologisk

ultrasonografi

Medisinsk avdeling

Haukeland universitetssykehus

og

Institutt for indremedisin

Universitetet i Bergen

En tidligere frisk mann i slutten av 30-årene ble innlagt $i$ sykehus på grunn av generelle ødemer og en vektøkning på ni kilo. Omtrent fem uker før innleggelsen hadde han hatt symptomer på halsbetennelse og fikk da penicillin. I de påfølgende ukene hadde han vært slapp og hatt feber og etter 2-3 uker lette epigastriesmerter $i$ forbindelse med spising. Ved klinisk undersøkelse på innleggelsestidspunktet ble det funnet generaliserte pittingødemer. Han var normotensiv og feberfri, og det var normal organstatus. Blodprøver viste albumin $11 \mathrm{~g} / \mathrm{l}(36-48 \mathrm{~g} / \mathrm{l})$, fibrinogen $1,8 \mathrm{~g} / \mathrm{l}(2,0-4,0 \mathrm{~g} / \mathrm{l})$ og totalprotein $24 \mathrm{~g} / \mathrm{l}(62-78 \mathrm{~g} / \mathrm{l})$. For $\varnothing v$ rig var det litt lav Na, $134 \mathrm{mmol} / \mathrm{l}$ (137-145 mmol/l), og INR-verdien var 1,2 $(<1,1)$. Verdiene for kreatinin, bilirubin, levertransaminaser, hemoglobin, trombocytter, CRP og leukocytter med differensialtelling var alle innenfor referanseområdet. Immunoglobuliner i serum var under referanseverdien: $\lg A$ 0,66 $\mathrm{g} / \mathrm{l}(1,00-4,10 \mathrm{~g} / \mathrm{l}), \lg \mathrm{G} 2,4 \mathrm{~g} / \mathrm{l}(6,00-15,3 \mathrm{~g} / \mathrm{l})$ og $\lg M 0,37 \mathrm{~g} / \mathrm{l}(0,50-2,50 \mathrm{~g} / \mathrm{l})$. Serum-elektroforese avslørte ingen monoklonale bånd. Urinstiks var svakt positiv på protein. Urin- mikroskopisk undersøkelse var normal. Proteinnivået $i$ døgnurin var $0,25 \mathrm{~g} / \mathrm{l} /<0,20$ $\mathrm{g} / \mathrm{l})$, Fekal kalprotektin $170 \mathrm{mg} / \mathrm{kg} \quad 10-50$ $\mathrm{mg} / \mathrm{kg}$ ).

Serologiske undersøkelse på virus viste positiv IgM spesifikk for cytomegalovirus (CMV), negativ lgG. Serologisk undersøkelse for Epstein-Barr-virus var negativ. Ultralyd abdomen inkludert dopplerundersøkelse av levervener viste lett forstørret milt, for $\emptyset$ vrig var det normale forhold. CT abdomen med kontrast viste forstørrede mesenterielle lymfeknuter, lett forstørret milt og noe ascites. Røntgen thorax viste noe pleuravæske.

Ultralydundersøkelse av hjertet viste pleuravæske, men det var ellers normalt.

Pasienten hadde altså akutte generelle ødemer, ascites og pleuravæske i forløpet av en halsbetennelse. Generelle ødemer kan skyldes økt hydrostatisk kapillært trykk pga. venøs obstruksjon eller økt plasmavolum ved saltretensjon. Hypoalbuminemi eller økt kapillær permeabilitet gir også ødemer. Ofte er det en kombinasjon av disse faktorene. Hjertesvikt er et klassisk eksempel på ødemer som skyldes saltretensjon og økt plasmavolum. Sepsis og brannskader er også tilstander som gir økt kapillær permeabilitet. Hypoproteinemi kan skyldes proteintap eller redusert proteinsyntese. Proteintap via nyrer eller gastrointestinaltractus ses. Ved leversvikt eller underernæringstilstander er det manglende proteinsyntese.

Hos vår pasient viste laboratorieprøver betydelig hypoalbuminemi. Ultralydundersøkelse av hjertet var normal. Man konkluderte med at ødemene skyldtes den lave albuminverdien. Med akutte symptomer og få andre funn er det mest nærliggende å tenke på proteintap via nyrene, som ved nefrotisk syndrom. Pasienten hadde imidlertid nesten normalt proteinnivå i døgnurin, og det var normal nyrefunksjon og normalt blodtrykk. Det var ingen tegn på underernæring eller leversvikt. Siden andre årsaker til hypoproteinemi var utelukket, ble arbeidsdiagnosen gastrointestinalt proteintap.
Han ble overflyttet til universitetssykehus for videre utredning. Etter overflyttingen var tilstanden og blodprøvene i hovedsak uendret. Serum-albumin var 16. Det ble tatt en diagnostisk ascitespunksjon som viste normalt antall leukocytter, en albuminverdi på $1 \mathrm{~g} / \mathrm{l}$ og en proteinverdi på $2 \mathrm{~g} / \mathrm{l}$ llave verdier). Serum-ascites-albumin-gradienten ble beregnet til 15. Det var ingen maligne celler $i$ ascitesvæsken. Ved PCR-undersøkelse for cytomegalusvirus i serum ble det påvist virus, men under $300 \mathrm{kopier} / \mathrm{ml}$.

Økningen i serum-albumin kunne tyde på en viss spontan bedring i tilstanden. Ascitesvæsken viste som ventet lave verdier både for protein og albumin. En serum-ascitesalbumin-gradient over 11 ses ved portal hypertensjon. Ultralyd av levervenene viste ingen tegn til dette hos vår pasient. En slik verdi utelukker tap av albumin til ascitesvæsken, som ved peritoneal malignitet eller abdominal tuberkulose.

Det ble utført en gastroenterologisk ultralydundersøkelse. Denne viste små mengder ascites og lett forstørret milt. Det mest påfallende funnet var imidlertid betydelig fortykket og foldet ventrikkelslimhinne, målt tykkelse var opp mot $2 \mathrm{~cm}$ (fig 1).

Ved gastroskopi ble det funnet betydelig hyperplastisk og ødematøs ventrikkelslimhinne $i$ corpus og fundus, med spredte erosive forandringer og skarp avgrensning mot normal antrumslimhinne. Det var negativ ureasetest.

Både endoskopi og ultralydundersøkelse ga mistanke om hyperplastisk gastropati. Et endoskopisk bilde med uttalt folding og for-

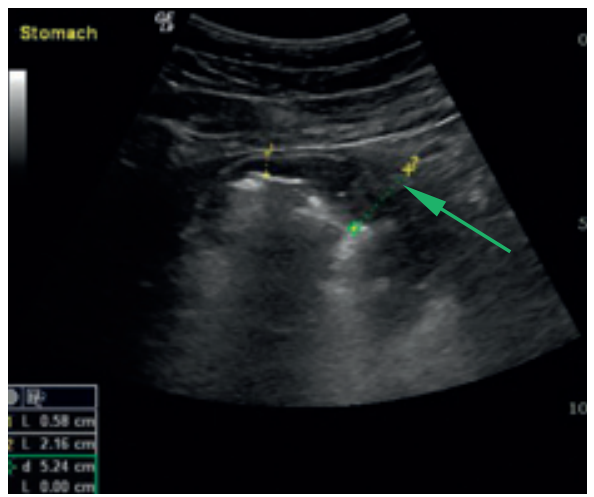

Figur 1 Transabdominal ultralyd (venstre) viser betydelig fortykket, foldet ventrikkelvegg. Tykkelsen er opp mot $2 \mathrm{~cm}$ (grønn pil) 

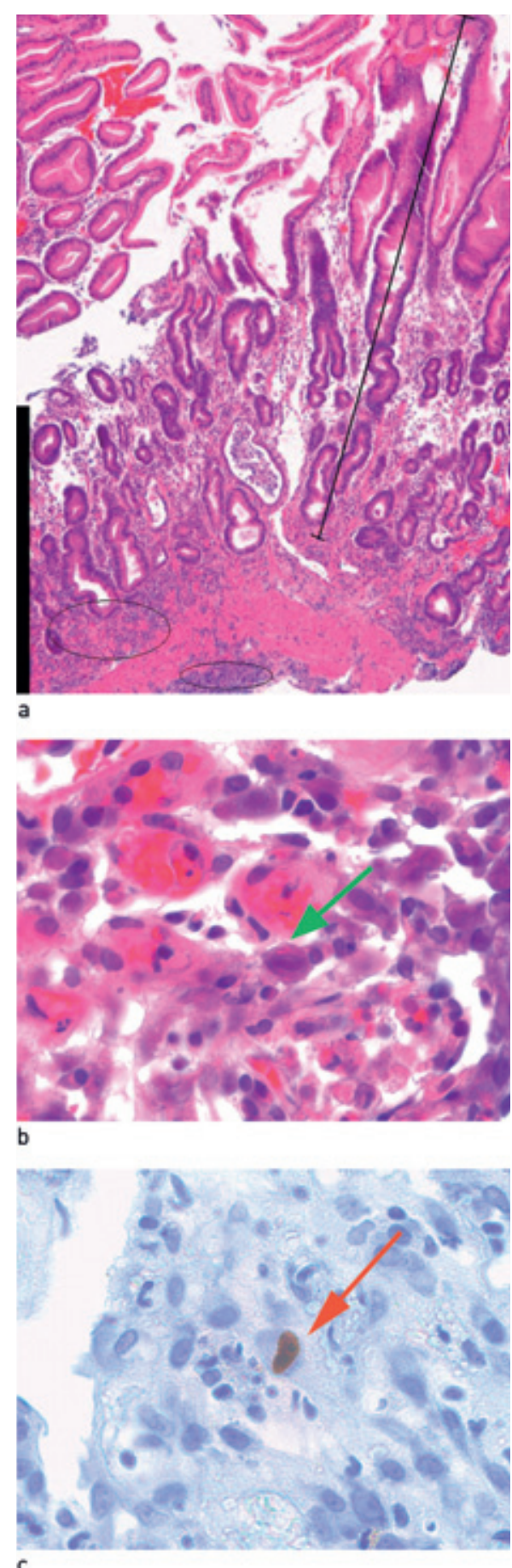

c

Figur 2 al Ventrikkelslimhinne av corpustype (H\&E-farging). Bemerk moderat foveolær hyper plasi (strek) og diffus betennelsesinfiltrat i lamina propria (ringer) (forstørret 100 ganger). b) Granulasjonsvev med noen celler med intranukleære (grønn pil) inklusjoner (H\&E-farging) (forstørret 400 ganger). c) Immunhistokjemisk fremstilt intranukleær inklusjon (rød pil) (forstørret 400 ganger)

tykket slimhinne passet ikke med ordinær gastritt. Sett i sammenheng med hypoalbuminemi som følge av gastrointestinalt proteintap mistenkte man Ménétriers sykdom. Dette er en idiopatisk tilstand med proteintap fra en fortykket og foldet ventrikkelslimhinne, histologisk dominert av hyperplasi i foveolært epitel.
Biopsier viste ventrikkelslimhinne av corpustype med hyperplastiske foveoler og dilaterte, lett slyngede krypter. Det var $ø k t$ mengde betennelsesceller i lamina propria og også affeksjon av enkelte kjertler. Betennelsescelleinfiltratet var dominert av nøytrofile granulocytter. Et av vevsfragmentene viste granulasjonsvev med et fåtall store celler med intranukleære inklusjoner. Immunhistokjemisk undersøkelse med antistoff mot cytomegalovirus (DAKO M M, clone $\mathrm{CCH} 2, \mathrm{M757}$ ) viste sterkt fargede kjerner i ytterst få, men forstørrede celler, noe som indikerer tilstedeværelse av virusprotein $i$ kjernene (fig 2). PCR-undersøkelse av biopsimateriale fra ventrikkelslimhinnen var positiv for cytomegalovirus..

Histologisk var det også trekk forbundet med Ménétriers sykdom, i form av moderat hyperplasi i foveolært epitel, men totalbildet var ikke typisk for denne diagnosen. Typiske inklusjonslegemer samt serologiske undersøkelser og PCR-undersøkelser fra både biopsier og serum ga mistanke om cytomegalovirus som utløsende agens. Virus ble også påvist med histologisk spesialfarging. Det er ikke mulig å skille mellom reaktivering av latent virus og aktuell primærinfeksjon. Det var ikke utført noen utredning av pasientens innledende halsbetennelse, men man kan selvsagt spekulere i om dette kan ha vært et ledd i CMV-infeksjonen.

En supplerende utredning ble utført med tanke på proteintap fra andre deler av gastrointestinaltractus. Det var normale funn ved koloskopi, men ved CMV-PCR ble det påvist virus i slimhinnen $i$ alle colonavsnitt. Det ble utført en enkel utredning av immunsvikt - test for hiv, komplement og leukocytter alt var normalt. Det samme var andre serologiske undersøkelser som ANA, AMA og ANCA.

Pasienten fikk intravenøs behandling med ganciklovir i 14 dager, så overgang til peroral valaciklovir i fem uker. I tillegg fikk han albumin intravenøst - $40 \mathrm{~g} / \mathrm{dag}-i$ en uke. Han fikk også diuretika for å mobilisere væske. Som følge av dette regimet gikk ødemene raskt tilbake og vekten ble normalisert. 14 dager etter oppstart av antiviral behandling ble det utført endoskopisk ultralydundersøkelse av ventrikkelen (fig 3a). Det var fortsatt forandringer, men man fikk inntrykk av tilbakegang. Ultralydbildet viste betydelig foldet og fortykket slimhinne, men tykkelsen ble nå målt til ca. 10 mm. Kapselendoskopi viste injiserte slimhinner $i$ ventrikkelen, for øvrig var det normale funn i tynntarmen.

Indikasjonen for antiviral behandling ved gastrointestinal CMV-infeksjon hos immunkompetente er ikke absolutt. Vi valgte å behandle pga. vedvarende alvorlig proteintap. Hvorfor vår pasient fikk så vidt alvorlig symptomgivende cytomegalovirusinfek- sjon, vites ikke. Utredningen har ikke avdekket noen form for immunsvikt.

Ny transabdominal og endoskopisk ultralydundersøkelse og endoskopi ble utført etter omtrent tre måneder. Denne viste tilnærmet normalisering av ventrikkelslimhinnen (fig 3b). Ut fra serologisk undersøkelse på cytomegalovirus fant man at det var skjedd en serokonvertering, med fall i lgM og stigning i spesifikt lgG. På dette stadium var pasienten frisk og alle blodprøver normale.

\section{Diskusjon}

Lavt serum-albuminnivå og ødemer ses ved en rekke tilstander. Gastrointestinalt proteintap er en eksklusjonsdiagnose når underernæring, proteinsyntesevikt i leveren og proteintap fra nyrene eller til peritoneum er utelukket. Det finnes ingen god metode for å anslå proteininnholdet $\mathrm{i}$ avføringen, og det er mange årsaker til proteintap via gastrointestinaltractus - noen forbigående, andre av mer kronisk art. Under utredningen bør man i første omgang ta sikte på å identifisere tilstander som krever spesifikk behandling. Man bør utelukke inflammatorisk tarmsykdom, malignitet og infeksiøse årsaker. Listen over differensialdiagnoser er lang og må vurderes i hvert enkelt tilfelle.

Ménétriers sykdom ble første gang beskrevet av Pierre Eugène Ménétrier i 1888 (1). I litteraturen er «Ménétriers sykdom» ofte brukt om enhver tilstand med store gastriske folder. Dette er dermed en upresis sykdomsklassifikasjon. Det er fornuftig å skille mellom rene hyperplastiske gastropatier (Ménétriers sykdom og Zollinger-Ellisons sykdom) og store gastriske folder, som er assosiert med andre tilstander. Med klassisk Ménétriers sykdom menes i dag en hyperplastisk gastropati der hyperplasien dominerer i foveolare epitelceller. Ved ZollingerEllisons sykdom dreier det seg om hyperplasi i parietalcellene. Lokalisasjonen ved Ménétriers sykdom er oftest begrenset til corpus og fundus ventriculi, med avgrensning mot et normalt antrum (2).

Klinisk domineres Ménétriers sykdom av varierende grad av proteintap og smerter øverst i abdomen. Klassiske tilfeller er ofte kroniske og behandlingsrefraktære, men en stor andel av pasientene kan også vise spontan bedring. Etiologien er ukjent. Hos dem med et klassisk sykdomsforløp har terapeutiske forsøk vist liten effekt. Ventrikkelreseksjon gir i de fleste tilfeller symptombedring (3).

Det er tidligere påvist at en stor gruppe av dem med Ménétriers sykdom var positive for Helicobacter pylori. Denne gruppen profitterer på eradikasjonsbehandling med antibiotika. I dag defineres dette som helicobactergastritt (4).

Cytomegalovirus er et virus i herpesvirusgruppen som vanligvis gir begrenset infeksjon hos immunkompetente. Etter primærinfeksjonen kan viruset gå inn i en latent fase. 

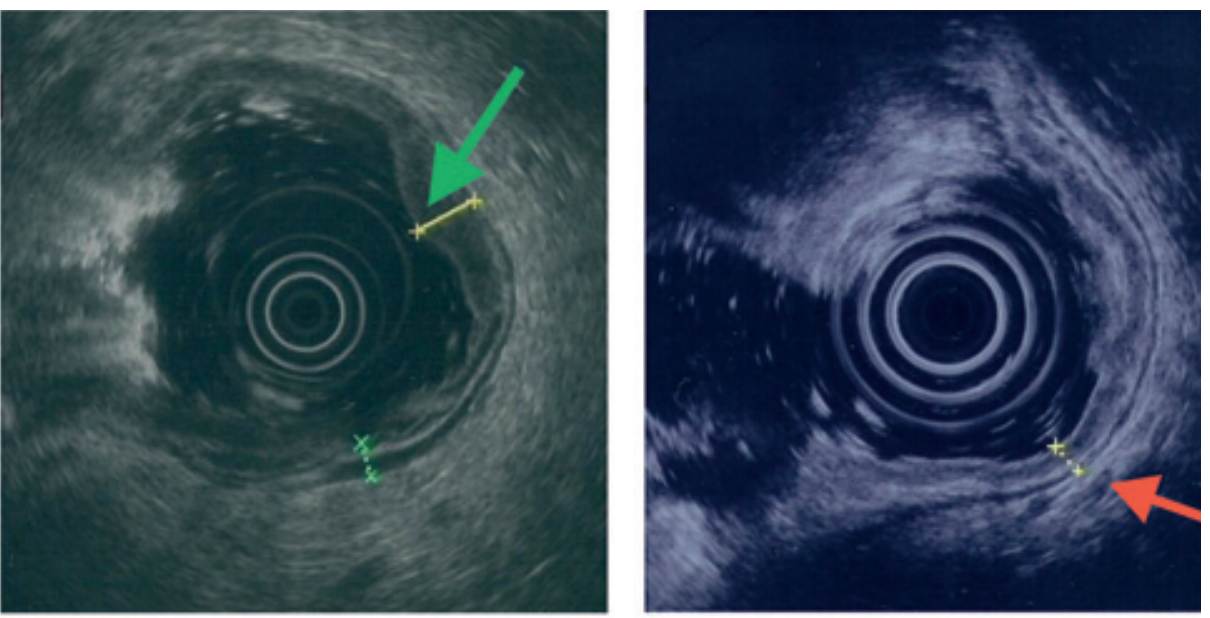
a

b

Figur 3 Endoskopisk ultralyd tatt a) 14 dager etter oppstart av antiviral behandling viser fortsatt fortykket ventrikkelslimhinne (grønn pill. b) Etter tre måneder er det tilnærmet normalisering av ventrikkelslimhinnens tykkelse (rød pil)

Hos immunsupprimerte er viruset vanligere som sykdomsfremkallende agens, både som primærinfeksjon og ved reaktivering av latent virus.

Diagnostisering av viruset i gastrointestinaltractus er vanskelig. To serologiske prøver med noe tidsavstand kan hjelpe til med å skille primærinfeksjon og reaktivering. Tilstedeværelse av spesifikt IgM alene kan ikke skille mellom primærinfeksjon og reaktivering. Senere serokonvertering med fallende IgM-nivå og signifikant stigning i IgGnivå taler for primærinfeksjon. Ved hjelp av PCR-teknikk kan man påvise virus både $i$ slimhinner og i avføring. Påvisning i små mengder uten slimhinneforandringer har usikker betydning. Ved tydelig slimhinneaffeksjon kombinert med histologiske funn av inklusjonslegemer i nukleus og cytoplasma i infiserte celler og positiv immunhistokjemisk farging med antistoff mot cytomegalovirus er aktuell infeksjon sannsynlig. Cytomegalovirusinfeksjoner er beskrevet i hele gastrointestinaltractus. Viruset kan gi hele spekteret av infeksjoner - fra enkle, asymptomatiske gastritter til alvorlige kolitter (5).

Etter søk i PubMed med «cytomegalovirus» og «Ménétrier» finner vi flere rapporter om en reversibel Ménétrier-liknende tilstand assosiert med cytomegalovirus hos barn (6, 7). Det finnes også noen svært få rapporter om en tilsvarende tilstand hos voksne, i de fleste tilfeller hos immunsupprimerte, men et liknende sykdomsbilde er også rapportert hos immunkompetente voksne. Hos flere er det forsøkt antiviral behandling, med god effekt. Spontan bedring uten behandling er også beskrevet (7-9).

Hyperplastiske ventrikkelslimhinner påvist ved endoskopi er et uspesifikt funn. Endoskopisk er det vanskelig å skille klassisk Ménétriers sykdom fra andre tilstander som gir liknende bilde. Transabdominal og endoskopisk ultralyd gir ofte en god fremstilling av slimhinnen $\mathrm{i}$ ventrikkelen og er et nyttig supplement (10).

Hos vår pasient ga endoskopi kombinert med transabdominal og endoskopisk ultralyd god fremstilling av en hyperplastisk gastropati. Det kliniske bildet pekte i retning av Ménétriers sykdom. Ved histologisk undersøkelse var epitelhyperplasien moderat. Veggfortykkelsen var mer dominert av betennelsesceller enn av foveolar slimhinnehyperplasi, som er typisk for Ménétriers sykdom. Histologien kunne tale i retning av infeksiøse forandringer. På grunnlag av supplerende etiologiske undersøkelser og sykdommens forløp etter behandling velger vi å gi vår pasient diagnosen reversibel cytomegalovirusindusert Ménétriers sykdom. Det er få rapporter om tilstanden hos voksne, flere hos barn. Det histologiske bildet samt sykdommens forløp i vårt tilfelle gjør at vi ikke kan definere dette som klassisk Ménétriers sykdom.

Pasienten har gitt samtykke til at artikkelen blir publisert.

\section{Oppgitte interessekonflikter: Ingen}

\section{Litteratur}

1. Ménétrier PE. Des polyadenomatoses gastriques et leurs rapport avec le cancer de l'estomac. Arch Physio Norm Pathol 1888; 32: 236.

2. Yardley J, Hendrix T. Hyperplastic gastropathies and other causes of enlarged gastric folds. Uptodate online 16.3. April 2006. http://utdol.com/ online/content/topic.do?topicKey=acidpep/9331 (4.2.2010).

3. Meuwissen S, Ridwan B, Hasper H et al. Hypertrophic protein-loosing gastropathy. A retrospective analysis of 40 cases in the Netherlands. The Dutch Ménétrier Study Group. Scand J Gastroenterol Suppl 1992; 194: 1-7.

4. Bayerdorffer E, Ritter M, Hatz R et al. Healing of protein losing hypertrophic gastropathy by eradication of Helicobacter pylori - is Helicobacter pylori a pathogenic factor in Ménétrier disease? Gut 1994; 35: 701-4

5. Moum B, Aukrust P, Bjørneklett A et al. Cytomegalovirussykdom I gastrointestinaltractus. Tidsskr Nor Lægeforen 1991; 111: 3388-91.

6. Sferra T, Pawel B, Qualman S et al. Ménétrier disease of childhood: role of cytomegalovirus and transforming growth factor alpha. J Pediatr 1996 : 128: $213-9$

7. Xiao SY, Hart J. Marked gastric foveolar hyperplasia associated with active cytomegalovirus infection. Am J Gastroenterol. 2001: 96: 223-6.

8. Pinho V, Ibrahim A, Avila Garavito A et al. Proteinlosing gastropathy associated with cytomegalovirus: a rare complication of allogenic bone marrow transplantation. Bone Marrow Transplant 1996; 17: 887-9.

9. Suter W, Neuweiler J, Borovicka J et al. Cytomegalovirus-induced transient protein-losing hypertophic gastropathy in an immuncompetent adult. Digestion 2000; 62: 276-9.

10. Gilja OH. Ultrasound of the stomach - EUROSON lecture 2006. Ultraschall Med 2007; 28: 32-9.

Manuskriptet ble mottatt 18.6. 2009 og godkjent 4.2. 2010. Medisinsk redaktør Siri Lunde.

\section{Et uvanlig proteintap i tarm}

Engjom og medarbeidere beskriver en grundig og reflektert utredning av en ung mann med ødemer, der resultatet viste seg overraskende. Selv om tilstanden mannen led av ikke er dagligdags medisin, utgjøres de «sjeldne tilfeller» av helt ordinære pasienter. Kun en systematisk tilnærming med god kunnskap om patofysiologi kan føre til en sikker diagnose.

I teorien kan en rekke tilstander føre til hypoalbuminemi, men flere av disse syntes helt uaktuelle (sepsis, brannskader, alvorlig underernæring m.m.). I fravær av slike åpenbare og/eller akutte mekanismer er det riktig å vurdere manglende syntese av proteiner $\mathrm{i}$ lever eller tap i nyrer. INR-verdi nær referanseområdet samt normale nivåer av leverenzymer og bilirubin gjorde leversykdommer usannsynlig. Ultralyd av lever bekreftet normalt organ, og man fant ikke alvorlig proteinuri. Ved gastroskopi fant man grove 